\title{
Intact individual heart cells isolated from human ventricular tissue
}

\author{
T POWELL, M F STURRIDGE, S K SUVARNA, D A TERRAR, V W TWIST
}

\begin{abstract}
The intricate architecture of heart muscle, comprising irregularly shaped cells which interdigitate in a complex three-dimensional array, has often compromised clear interpretation of experimental data obtained from the whole organ. One approach to minimise some of the difficulties is to use individual muscle cells in suspension, and data have already been reported using myocytes isolated from mammalian ventricles. It is difficult, however, to extrapolate results obtained from animal tissues to situations of medical relevance in man. Intact isolated muscle cells were obtained from human ventricular tissue by modifications of methods used for isolating smooth muscle, atrial, and ventricular tissue from animals. Electrical studies showed that these myocytes had functional characteristics similar to those observed in the whole heart.

Such cells will prove a useful preparation for studies on both the mechanisms underlying myocardial performance in normal and diseased states and the response of heart tissue at the cellular level to conditions found during cardiac surgery.
\end{abstract}

\section{Introduction}

Studies on the mechanisms underlying myocardial performance in both normal and diseased states have often been hampered by the complex morphology and syncytial function of the whole heart. One promising experimental approach to minimise some of these complexities has been the enzymic dispersion of adult

\footnotetext{
Middlesex Hospital and Medical School, London W1P 6DB

T POWELL, PHD, DPHIL, senior lecturer, department of physics as applied to medicine

M F STURRIDGE, MS, FRCS, consultant cardiothoracic surgeon

S K SUVARNA, BSC, medical student

D A TERRAR, PHD, senior lecturer, department of pharmacology and therapeutics

$\mathrm{V}$ W TWIST, BSC, research assistant, department of physics as applied to medicine
}

cardiac tissue into a suspension of intact cells. Work in our laboratory has shown that such a technique can provide individual myocytes from the ventricles of rats, ${ }^{1-3}$ and other workers have obtained cells from the hearts of rabbits ${ }^{4}$ and dogs. ${ }^{5}$ Our studies have shown that isolated cells retain the morphological features characteristic of myocytes studied in the whole organ, ${ }^{126} 7$ and have acceptable electrical properties ${ }^{3} 8$ and responses to the administration of catecholamines. ${ }^{9-11}$ Nevertheless, it is difficult and often misleading to extrapolate experimental results in animal tissues to man. We describe here, for the first time, a technique for obtaining isolated intact myocardial cells from human ventricular tissue and show that these individual myocytes have morphological and electrical characteristics consistent with those observed in the whole heart.

\section{Methods}

Tissue, excised from patients undergoing corrective open-heart surgery, was obtained in theatre immediately on removal. Samples were from either the right ventricle of children undergoing correction of Fallot's tetralogy or papillary muscle of patients undergoing mitral valve replacement. These samples, which varied in size and shape but generally had a maximum length of $3-8 \mathrm{~mm}$, were placed in a sterilised container holding a Krebs-Ringer solution of the following composition: $\mathrm{NaCl} 118.5 \mathrm{mmol} / \mathrm{l}, \mathrm{KCl} 4.2 \mathrm{mmol} / 1, \mathrm{NaHCO}_{3} 14.5$ $\mathrm{mmol} / 1, \mathrm{KH}_{2} \mathrm{PO}_{4} 1.18 \mathrm{mmol} / \mathrm{l}, \mathrm{MgSO}_{4} 1.18 \mathrm{mmol} / \mathrm{l}$, glucose $11 \cdot 1$ $\mathrm{mmol} / \mathrm{l}$; this solution was gassed with $95 \% \mathrm{O}_{2} / 5 \% \mathrm{CO}_{2}$ to maintain $\mathrm{pH}$ at $7 \cdot 40 \pm 0 \cdot 05$.

The tissue was transported to the laboratory within 10-15 minutes of removal and then cut into cubes of varying dimensions by a mechanical tissue chopper ${ }^{3}$ with a blade interval setting of $1 \mathrm{~mm}$. The chopped tissue was placed in a polytetrafluoroethylene beaker containing $10 \mathrm{ml}$ of Krebs-Ringer solution, which had been preincubated at $37^{\circ} \mathrm{C}$ and to which had been added $1 \mathrm{mg} / \mathrm{ml}$ lyophilised trypsin $(236 \mathrm{U} / \mathrm{mg}), 1.5 \mathrm{mg} / \mathrm{ml}$ crude bacterial collagenase (type 1 , Clostridium histolyticum, $175 \mathrm{U} / \mathrm{mg}$ ), $10 \mathrm{mg} / \mathrm{ml}$ bovine serum albumin, and $100 \mathrm{U} / \mathrm{ml}$ of benzylpenicillin and streptomycin. This mixture was incubated at $37^{\circ} \mathrm{C}$ for 40 minutes, stirred continuously at $2 \mathrm{~Hz}$ by a stainless steel paddle, and gased from above with humidified oxygen-carbon dioxide mixture.

At the end of this period the stirring was stopped and the tissue allowed to settle. The supernatant was removed carefully and replaced by $10 \mathrm{ml}$ of preincubated buffer containing an additional $1 \mathrm{mg} / \mathrm{ml}$ of bovine serum albumin free of fatty acids. This incubation was carried out for five minutes, the solution was then removed from the 
settled tissue fragments, and $10 \mathrm{ml}$ of Krebs-Ringer solution containing $0.5 \mathrm{mg} / \mathrm{ml}$ of crude collagenase was added. Incubation was continued, with stirring, for up to 75 minutes, with frequent microscopic examination of the supernatant (every 10-15 minutes) to assess the quality and quantity of cell yield.

When cell numbers had stabilised the incubation medium was filtered through $250-\mu \mathrm{m}$ nylon gauze and the cells washed by one of two methods. Either the filtered suspension was centrifuged at $22 \mathrm{~g}$ for one minute or $2.5 \mathrm{ml}$ aliquots were placed in $10-\mathrm{ml}$ siliconised tubes, diluted to $5 \mathrm{ml}$ with albumin-free Krebs-Ringer solution, and the cells allowed to sediment under gravity for 15 minutes at room temperature. After centrifugation cell pellets were suspended in $5 \mathrm{ml}$ Krebs-Ringer solution containing $10 \mathrm{mg} / \mathrm{ml}$ bovine serum albumin. For sedimented cells the bottom $2 \mathrm{ml}$ of solution in each sedimentation tube was diluted with an equal volume of buffer and the fractions pooled. Cell suspensions were stored at room temperature in siliconised flasks and gassed at regular intervals. These isolation procedures were modifications of methods used for dispersing smooth muscle, ${ }^{1213}$ atrial, ${ }^{14}$ and ventricular ${ }^{315}{ }^{16}$ tissue from animals. We used conventional techniques ${ }^{3}$ for recording cellular electrical activity, using intracellular glass microelectrodes containing $3 \mathrm{M} \mathrm{KCl}$ and having resistances in the range $35-80 \mathrm{M} \Omega$. A system incorporating a bridge circuit ${ }^{311}$ was used in most of the experiments.

\section{Results}

Attempts to dissociate cells from tissue obtained from adults were unsuccessful, but six successful experiments were carried out on samples taken from the infundibulum of the right ventricles of children (aged 4 to 10 years, both boys and girls) undergoing correction of Fallot's tetralogy. Maximum yields of cells were obtained after 40-50 minutes of the final incubation with collagenase (see Methods); fig 1 shows the appearance of two isolated myocytes as typical examples.

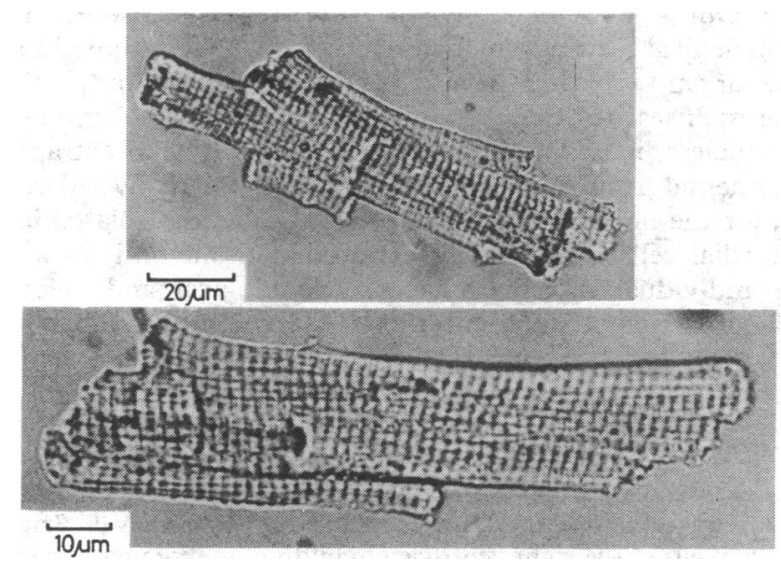

FIG 1-Light micrographs of two isolated ventricular muscle cells. Note regular cross striations and also irregular cell contours, particularly at the ends; both of these characteristics are simliar to those observed in cells in vivo. Cell $a$ is $118 \mu \mathrm{m}$ long and cell $b 121 \mu \mathrm{m}$ long.

Cells were irregular, $60-140 \mu \mathrm{m}$ long and $10-30 \mu \mathrm{m}$ wide, with clear cytoplasm and distinct cross-striations. These features were consistent with those observed for myocytes isolated from other mammalian species, ${ }^{124-616}$ the non-uniformity of cell shapes reflecting the complex geometrical arrangement of ventricular muscle.

Although cells were quiescent, they could be stimulated electrically to give action potentials (fig 2) which evolved from membrane potentials more negative than $-80 \mathrm{mV}$. The action potential in fig 2(a) was from a cell with a resting potential of $-90 \mathrm{mV}$, with an overshoot of $31 \mathrm{mV}$ and a duration (to $90 \%$ of repolarisation) of $75 \mathrm{~ms}$. In fig $2(b)$ the initial membrane potential was $-82 \mathrm{mV}$, overshoot $26 \mathrm{mV}$, and duration of action potential $520 \mathrm{~ms}$. These values indicate the range of measurements obtained from individual cells and are comparable with recordings which have been reported for human multicellular preparations. ${ }^{17}$ Furthermore, cells could be paced at varying rates by either an intracellular microelectrode or field stimulation with plate electrodes. Results such as those shown in fig 2 could be obtained for at least six hours after the cell was isolated.

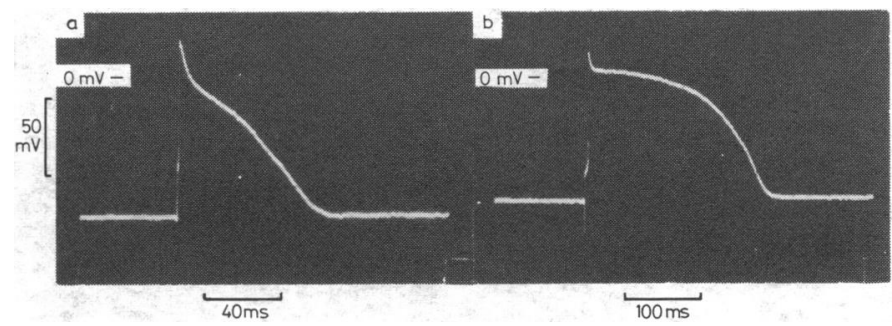

FIG 2-Action potentials recorded from two individual myocytes with a glass microelectrode. Both cells were paced at $1 \mathrm{~Hz}$ and bathed in KrebsRinger solution containing $1 \mathrm{mmol} / 1$ calcium chloride, temperature $25 \cdot 5^{\circ} \mathrm{C}$.

\section{Discussion}

Individual cells isolated from mammalian ventricles of animal origin have already provided interesting information on the electrical characteristics of myocytes uncoupled physically from their usual syncytial state, ${ }^{3}$ which is relevant to cells in vivo uncoupled electrically in regions of ischaemia or local mechanical damage. Experimental results have been reported on the ionic currents important for both cardiac impulse conduction ${ }^{18-22}$ and development of the force of contraction. ${ }^{112324}$ Data have also been published on the biochemical characteristics of isolated cells, ${ }^{25-30}$ including their responses to hormones ${ }^{25}{ }^{26}$ and the onset of anoxia. ${ }^{2630}$ Our demonstration that it is now possible to obtain isolated cells from human tissue should not only prompt experiments designed to provide comparable evidence of direct clinical relevance in man but will also be an impetus to investigate both the response and preservation of myocardial tissue at cellular level in circumstances commonly encountered during cardiac surgery.

This research was supported by grants from the British Heart Foundation and the MRC.

\section{References}

1 Gould RP, Powell T. Intact isolated muscle cells from the adult rat heart. f Physiol 1972;225:16-9P.

2 Powell T, Twist VW. A rapid technique for the isolation and purification of adult cardiac muscle cells having respiratory control and a tolerance to clacium. Biochem Biophys Res Commun 1976;72:327-33.

${ }^{3}$ Powell T, Terrar DA, Twist VW. Electrical properties of individual cells isolated from adult rat ventricular myocardium. F Physiol 1980;302: 131-53.

4 Dani AM, Cittadini A, Flamini G, Festuccia G, Tarranova T. Preparation and some properties of isolated beating myocytes from adult rabbit heart. $\mathcal{F}$ Mol Cell Cardiol 1977;9:777-84.

5 Vahouny GV, Wei RW, Tamboli A, Albert EN. Adult canine myocytes: isolation, morphology and biochemical characteristics. $\mathcal{f}$ Mol Cell Cardiol 1979;11:339-57.

${ }^{6}$ Powell T, Steen EM, Twist VW, Woolf N. Surface characteristics of cells isolated from adult rat myocardium. F Mol Cell Cardiol 1978;10:287-92.

${ }^{7}$ Severs NJ, Powell T. Sarcolemma structure in isolated rat myocytes. Electron Microsc 1980;2:134-5.

${ }^{8}$ Powell T, Terrar DA, Twist VW. Membrane potentials in muscle cells isolated from adult rat myocardium. F Physiol 1978;382:23-4P.

9 Powell T, Twist VW. Isoprenaline stimulation of cyclic AMP production by isolated cells from adult rat myocardium. Biochem Biophys Res Commun 1976;72:1218-25.

${ }^{10}$ Powell T, Terrar DA, Twist VW. Electrical activity in superfused cells isolated from adult rat myocardium. F Physiol 1978;284:148P.

11 Powell T, Terrar DA, Twist VW. The effect of noradrenaline on slow inward current in rat ventricular myocytes. Proc Physiol Soc 1981; June: $107 \mathrm{P}$.

12 Bagby RM, Young AM, Dotson RS, Fisher BA, McKinnon K. Contractions of single smooth muscle cells from Bufo marinus stomach. Nature $1971 ; 234$ :351-2.

13 Fay FS, Delise CM. Contraction of isolated smooth muscle cellsstructural changes. Proc Natl Acad Sci USA 1973;70:641-5.

14 Hume JR, Giles W. Active and passive electrical properties of single bullfrog atrial cells. $\mathcal{F}$ Gen Physiol $1981 ; 78: 19-42$.

15 Kono $T$. Roles of collagenases and other proteolytic enzymes in the dispersal of animal tissues. Biochim Biophys Acta 1969;178:397-400.

16 Vahouny GV, Wei R, Starkweather R, Davies C. Preparation of beating heart cells from adult rat. Science 1970;167:1616-8.

17 Trautwein W, Kassebaum DG, Nelson RM, Hecht HH. Electrophysiological study of human heart muscle. Circ Res 1962;10:306-12. 
${ }^{18}$ Lee KS, Weeks TA, Kao RL, Akaike N, Brown AM. Sodium current in single heart muscle cells. Nature 1979;278:269-71.

19 Brown AM, Lee KS, Powell T. Reactivation of sodium conductance in single heart muscle cells. F Physiol 1980;301:78-9P.

${ }^{20}$ Lee KS, Hume JR, Giles W, Brown AM. Sodium current depression by lidocaine and quinidine in isolated ventricular cells. Nature $1981 ; 291$ : 325-7.

${ }^{21}$ Brown AM, Lee KS, Powell T. Voltage clamp and internal perfusion of single rat heart muscle cells. $\mathcal{F}$ Physiol $1981 ; 318: 455-77$.

22 Brown AM, Lee KS, Powell T. Sodium current in single rat heart muscle cells. F Physiol 1981;318:477-500.

${ }^{23}$ Isenberg G, Klockner $U$. Glycocalyx is not required for slow inward calcium current in isolated rat heart myocytes. Nature $1980 ; 284: 358-61$.

${ }^{24}$ Lee KS, Lee EW, Tsien RW. Slow inward current carried by $\mathrm{Ca}^{2}+$ or $\mathrm{Ba}^{2}$ ? in single isolated heart cells. Biophys $\mathcal{F} 1981 ; 33: 143 \mathrm{a}$.

${ }^{25}$ Eckel J, Reinauer $H$. Characteristics of insulin receptors in the heart muscle. Binding of insulin to isolated muscle cells from adult rat heart. Biochim Biophys Acta 1980;629:510-21.
${ }^{26}$ Kao RL, Christman EW, Luh SL, Krauhs JM, Tyers GFO, Williams EH. The effects of insulin and anoxia on the metabolism of isolated mature rat cardiac myocytes. Arch Biochem Biophys 1980;203:587-99.

27 Bahl J, Navin T, Manian AA, Bressler R. Carnitine transport in isolated adult rat heart myocytes and the effect of 7,8 diOH chlorpromazine. Circ Res $1981 ; 48: 378-85$.

${ }^{28}$ Montini J, Bagby GJ, Burns AH, Spitzer JJ. Exogenous substrate utilization in $\mathrm{Ca}^{2+}$-tolerant myocytes from adult rat hearts. Am $\mathcal{F}$ Physiol $1981 ; \mathrm{H} 659-\mathrm{H} 663$.

29 Wittenberg BA, Robinson TF. Oxygen requirements, morphology, cell coat and membrane permeability of calcium-tolerant myocytes from hearts of adult rats. Cell Tissue Res $1981 ; 216: 231-51$.

${ }^{30}$ Dow JW, Walker EJ. Features of cardiac myocytes in culture: characterisation of the failing cell. In: Longmore DB, ed. Towards safer cardiac surgery. MTP Press: Lancaster, 1981.

(Accepted 21 September 1981)

\section{Abstract}

Diaphragm pacing, which entails electrical stimulation to the phrenic nerve, is an effective means of managing patients with ventilatory insufficiency and intact lowermotor-neurone innervation of the diaphragm. The pacing apparatus is used to pace the right and left hemidiaphragms alternately to avoid fatigue, which may damage the muscle irreversibly.

Among the important benefits of pacing in quadriplegics with paralysis of respiratory muscles are the social and psychological advantages of not being dependent on a mechanical ventilator.

\section{Introduction}

Electrical stimulation of the phrenic nerve to effect ventilation for prolonged periods was first reported by Judson and Glenn in 1968. Since then the technique of diaphragm pacing has been used in over 180 patients in America, and we describe here what we believe to be the first case of its use in Britain.

\section{Case report}

A 42-year-old man was admitted to hospital in January 1980 having fallen headlong downstairs. On examination he was quadriplegic, with all respiratory movements being achieved by the sternomastoid and scalene accessory muscles. $X$-ray examination of the cervical spine showed an odontoid anomaly that was stable. He was observed initially and by the following day was becoming exhausted, so after endotracheal intubation positive-pressure ventilation was started and a tracheostomy performed. When the ventilator was stopped he could maintain a tidal volume of about $100 \mathrm{ml}$ for up to six minutes. Operative treatment was not indicated, and as the neurological lesion was incomplete there was a slight chance of recovery of phrenic activity. $X$-ray screening of

Chest Unit, Department of Anaesthesia, and Department of Neurosurgery, King's College Hospital, London SE5 8RX

$S$ LOZEWICZ, MB, MRCP, medical registrar (present address: Cardiothoracic Institute, London SW $36 \mathrm{HP}$

D R POTTER, MB, FFARCS, consultant anaesthetist

J F COSTELLO, MB, MRCP, consultant physician

J B MOYLE, MB, FFARCS, anaesthetic registrar

J J MACCABE, MB, FRCS, consultant neurosurgeon the diaphragm in March, however, showed no voluntary movement on either side, and his suitability for implanted diaphragm pacemakers was further investigated. Percutaneous stimulation of each phrenic nerve produced adequate tidal volumes and visible excursion of the diaphragm on screening.

Receivers and electrodes of the pacemaker system were implanted by one of us (JJM) on the right side in September and on the left side six weeks later. The diaphragm was paced for short periods initially, but the duration of stimulation was gradually increased and the time spent on the ventilator became less. The pacing apparatus was adjusted to produce 12 respirations a minute with a tidal volume of about $440 \mathrm{ml}$ during stimulation of the right and $460 \mathrm{ml}$ during stimulation of the left hemidiaphragm with the patient supine. Arterial tensions of oxygen and carbon dioxide were in the normal range after four hours' continuous pacing on either side. The tracheostomy was maintained with a 24 French gauge plain Portex tube, which was occluded during the day, except when required for tracheal suction, to facilitate normal speech. At present each hemidiaphragm is paced alternately for eight-hour periods, so removing altogether the need for positive-pressure ventilation.

\section{Discussion}

The diaphragm pacer uses integrated solid-state electronic circuitry to permit delivery of an adjustable electrical stimulus to the phrenic nerve. The apparatus has been described in detail by Glenn $e t a^{2}{ }^{3}$ (Avery Laboratories, Farmingdale, New York 11735). An external battery-powered transmitter develops a radiofrequency signal, which is radiated from a loop antenna. This antenna is placed over a subcutaneous radioreceiver, which is usually implanted just above the costal margin in the mid or anterior axillary line. The receiver is encapsulated in an epoxy disc and covered in silicone rubber. It demodulates the signal, and the resulting direct-current pulses pass to an electrode placed on the phrenic nerve usually in the neck (figure). The delivery of a train of about 25 electrical pulses to the phrenic nerve over approximately 1.3 seconds produces contraction of the diaphragm. By using the controls on the external transmitter it is possible to alter the respiration rate, which represents the time interval between adjacent pulse trains, and the inspiration time, which is determined by the duration of each pulse train. The amplitude of the stimulating current determines the depth of inspiration and is also adjustable.

Glenn has had the most extensive experience with diaphragm pacing. He has reported its use in 36 patients with central alveolar hypoventilation, in one patient with chronic obstructive lung disease, and in 20 quadriplegics with paralysis of the 